\title{
Carcinoid tumor of the gallbladder
}

\author{
Department of Surgery, Universidade de São Paulo - São Paulo, Brazil
}

\begin{abstract}
The carcinoid tumor is a relatively rare type of endocrine tumor, which arises mainly in the gastrointestinal tract. Primary gallbladder and biliary duct system carcinoids comprise less than $1 \%$ of all carcinoid tumors arising from any tissue or organ in the body. We describe a case of carcinoid tumor of the gallbladder in a 39-year-old man. There have been only 32 cases described in the literature.
\end{abstract}

UNITERMS: Gallbladder. Carcinoid tumor. Surgery.

\section{INTRODUCTION}

$\mathrm{T}$ he carcinoid tumor is a relatively rare type of endocrine tumor, which arises mainly in the gastrointestinal tract. $^{(1)}$

Primary gallbladder and biliary duct system carcinoids comprise less than $1 \%$ of all carcinoid tumors arising from any tissue or organ in the body. We describe a case of carcinoid tumor of the gallbladder in a 39-yearold man. There have been only 32 cases described in the literature. ${ }^{(1-3)}$

\section{Address for correspondence:}

Marcel A. C. Machado

Al. Casa Branca, 438 Apto 101

São Paulo/SP - Brasil - CEP 0108-001

e-mail :mmautran@dedalus.net

\section{CASE REPORT}

A 39-year-old man presented a six year history of mild abdominal distension associated with fat intolerance. There was no pertinent past medical or surgical history. His vital signs were normal and his sclera were anicteric. Abdominal examination revealed no tenderness, organomegaly, or abnormal mass.

Laboratory data included normal hematological findings and serum electrolyte levels. Liver function studies revealed the following values: total bilirubin, 0.8 $\mathrm{mg} / \mathrm{dl}$; direct bilirubin $0.2 \mathrm{mg} / \mathrm{dl}$; alkaline phosphatase, 89 IU/L (normal level: 60 to $170 \mathrm{IU} / \mathrm{L}$ ); aspartate aminotransferase, $10 \mathrm{IU} / \mathrm{L}$ (normal level: 0 to $18 \mathrm{IU} / \mathrm{L}$ ); and alanine aminotransferase, $18 \mathrm{IU} / \mathrm{L}$ (normal level: 0 to $18 \mathrm{IU} / \mathrm{L})$. Abdominal ultrasound revealed a $6.4 \mathrm{~cm}$ soft tissue mass that appeared to arise from the wall of the gallbladder. CT scan showed a large tumor with soft tissue density in the gallbladder without evidence of calcification (Figure 1). 


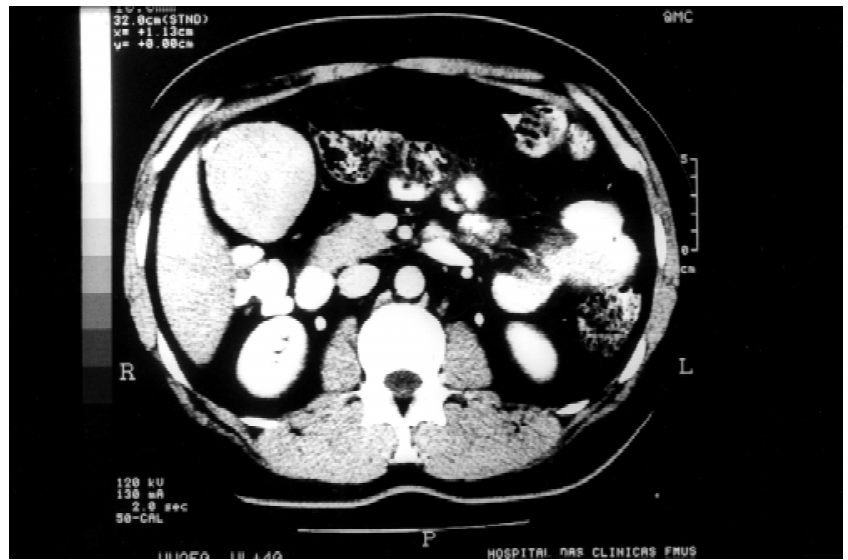

Figure 1. Computerized tomograph showing tumor in gallbladder.

The patient was referred for surgical opinion and laparotomy was subsequently performed. At laparotomy a 7 x $6 \mathrm{~cm}$ hypervascularized mass was found within the gallbladder wall, located on the free surface of the fundus of the gallbladder. The tumor was freely mobile and did not appear to extend into the liver or adjacent organs. There was no evidence of liver metastases or gangliar involvement. The gallbladder and the tumor were removed together and intact. Intraoperative cholangiography was normal. Pathological examination revealed an intramural tumor $6.5 \mathrm{~cm}$ in diameter in the free wall of the fundus of the gallbladder (Figure 2). Adjacent mucosa showed a $2 \mathrm{~cm}$ area of ulceration. Microscopic examination showed a carcinoid tumor (Figure 3). The tumor had infiltrated into the mucosa extensively, penetrated the muscular layer and extended into the serosa but was completely excised with free resection margins. The tumor cells were positive for chromogranin and S-100 protein. The patient is still alive 2 years after cholecystectomy.

\section{DISCUSSION}

The bile ducts and gallbladder in particular are extremely rare sites for carcinoids. ${ }^{(4)}$ Primary gallbladder carcinoids represent less than $1 \%$ of all carcinoid tumors. The first case of primary carcinoid tumor of the gallbladder was reported in 1929 and since then a further 32 cases have been reported in Western literature. ${ }^{(1,2,3)}$

From the published data including our patient, the age at presentation ranged from 26 to 84 years (mean age: 61.9 years). There were 22 women and nine men, and two further case reports did not give details of the patient's sex.
Preoperative diagnosis of carcinoid tumor of the gallbladder is difficult, mainly because of its small size and limitations in the resolution of available radiological techniques. ${ }^{(1)}$ In some patients, as in the present case, a mass in the gallbladder was identified but determination of histologic type of tumor and diagnosis to differentiate from gallbladder adenocarcinoma is often difficult. Furthermore, the carcinoid syndrome has been found in only two patients, both of whom had disseminated disease. Most of the tumors were undetected before surgery, however, and in the absence of other signs, such as the carcinoid syndrome (two cases), preoperative diagnosis was not made.

The surgical management employed in these patients has varied, ranging from simple cholecystectomy (including one case of laparoscopic cholecystectomy) to more extensive surgical resections, including regional lymphadenectomy and hepatectomy.

The survival rate of patients with carcinoid tumors is most directly related to the malignant potential of the tumors. Several factors have been found to be important in determining malignancy. First of all, the site of origin, because $60 \%$ of colon carcinoids demonstrate metastases at the time of diagnosis, whereas only $2 \%$ of appendiceal carcinoids have metastases. Second, the size of the tumor is important, because only $6 \%$ of primary tumors less than $1 \mathrm{~cm}$ in diameter are associated with metastases, whereas $70 \%$ of tumors $2 \mathrm{~cm}$ or larger have metastases. Third, the presence of multicentric primary tumors is associated with an increased malignancy risk. Fourth, the depth of penetration into the organ wall is important, with increased malignancy rates noted as the tumor invades beyond the submucosa to the muscle itself, the serosa and beyond. Other factors associated with determination of malignancy potential include the histologic growth pattern and the nuclear DNA content. ${ }^{(1)}$

Specific prognostic factors have not been identified in patients with gallbladder carcinoids and the usual criteria

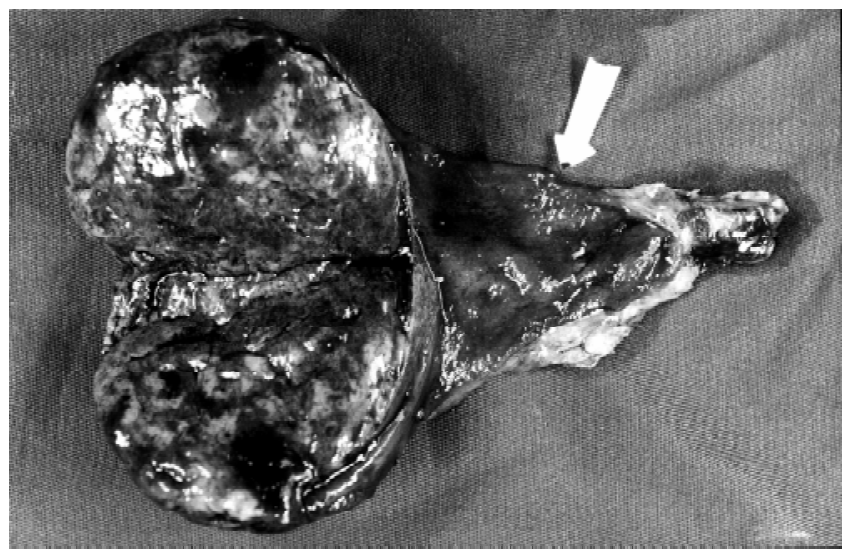

Figure 2. Macroscopic appearence of surgical specimen presenting enormous tumoral mass in the fundus of the gallbladder. 


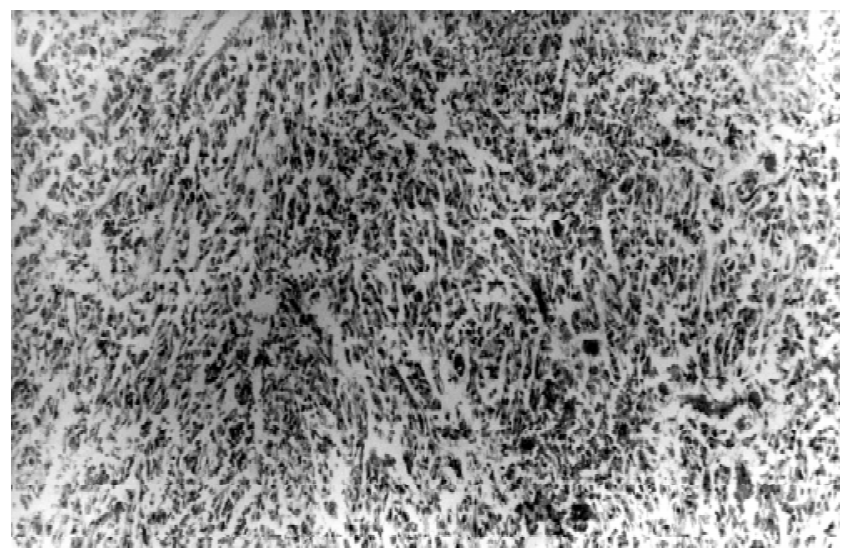

Figure 3. Microscopic appearence of carcinoid tumor in gallbladder (HE x 100).

for judging malignancy, such as anaplasia and mitotic figures, are unreliable in these sites of carcinoid tumor. ${ }^{(3)}$ Malignancy is well determined from evidence of tumor invasion into adjacent structures. If the tumor is localized to the gallbladder wall, with no evidence of intraperitoneal or metastatic spread, these patients have a better prognosis. But, if there is deep invasion in the organ wall, as in our case, the prognosis is uncertain. ${ }^{(3)}$

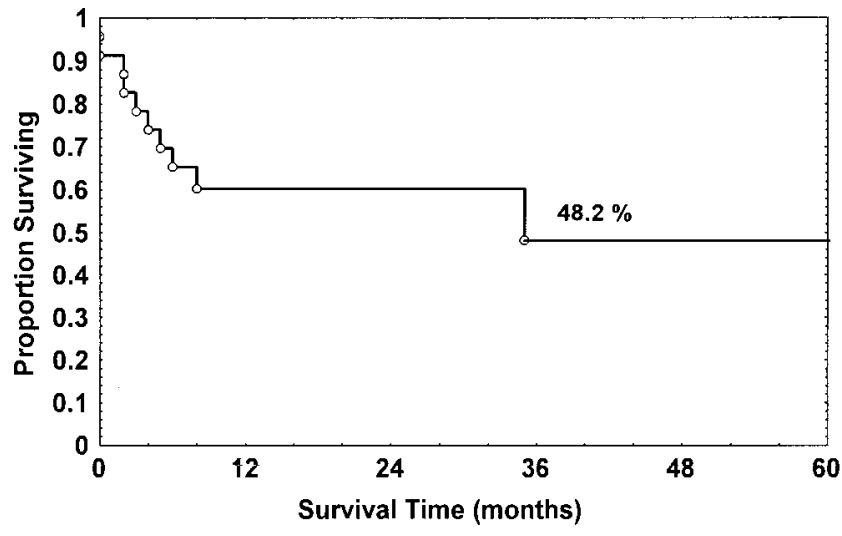

Figure 4. Cumulative survival of patients with carcinoid tumor in gallbladder, after kaplan-meier.

In the 23 patients with outcomes available in the literature, two died in the immediate postoperative period. The 3-year cumulative survival rate was $48.2 \%$ (Figure 4). The addition of chemotherapy or radiotherapy, or both did not change the survival. The median survival of all patients is 30 months. Different from Deehan et al, ${ }^{(1)}$ we did not find a difference in survival according to the sex of the patient $(\mathrm{p}=0.24)$.

\section{ReSUMO}

O tumor carcinóide é um tipo relativamente raro de tumor endócrino que é mais freqüentemente encontrado no trato gastrointestinal. Os tumores carcinóides da vesícula e vias biliares correspondem a menos de $1 \%$ de todos os tumores carcinóides do organismo humano. Nós apresentamos um caso raro de carcinóide da vesícula biliar em paciente de 39 anos, do sexo masculino. Existem somente 32 relatos prévios de casos semelhantes na literatura.

\section{REFERENCES}

1. Deehan DJ, Heys SD, Kernohan N, Eremin O. Carcinoid tumor of the gall bladder: two case reports and a review of published works. Gut 1993;34:1274-6.

2. Brown WM 3d, Henderson JM, Kennedy JC. Carcinoid tumor of the bile duct: a case report and literature review. American Surgeon 1990;56:343-6.
3. Porter JM, Kalloo AN, Abernathy EC, Yeo CJ. Carcinoid tumor of the gallbladder: laparoscopic resection and review of the literature. Surgery 1992;112:100-5.

4. Machado MCC, Penteado S, Bacchella T, Bettarello A, Cunha JEM, Faintuch J, Lopes HLC, Raia A. Carcinoide da confluência dos ductos hepáticos principais. Rev Hosp Clin Fac Med São Paulo 1981;36:139-42. 